\title{
연구논문
}

\section{Prevention and Resolution of Conflicts on Development and Environment in Korea}

\author{
Lee, Jong Ho \\ Department of Urban Planning, Cheongju University \\ (Manuscript received 8 January 2013; accepted 21 January 2013) \\ 개발관련 갈등의 예방과 해소방안 \\ 이 종 호 \\ 청주대학교 도시계획학과 \\ (2013년 1월 8일 접수, 2013년 1월 21일 승인)
}

\begin{abstract}
정부 주도의 대규모 개발사업은 개발과 환경보전이라는 가치관의 차이, 개발로 인한 공익과 환경 파괴로 인한 환경이익 침해와 같은 공익 간의 상충, 사업으로 예상되는 국익과 개인의 재산권 침해 등과 같은 문제를 초래하는 경우가 많았다. 그럼에도 불구하고 정부는 개발정책과 계획을 수립하고 개발사업을 집행하는 과정에서 발생되는 자연훼손이나 환경파괴, 경제적 타당성, 사회적 문제 등을 객관적이고 과학적으로 조사하거나 제대로 검증하지 않아 갈등이 빈번하게 발생하였다.

이러한 갈등을 해결하기 위한 기존의 연구는 대개 갈등의 원인을 이해관계, 가치관, 사실관계, 제 도 측면에서 규명하고 해결방안으로 주로 주민참여와 거버넌스, 전략환경평가, 사회영향평가 등을 제시하였다.

본 연구에서는 한국에서 1980 년대 중반이후 주요 개발갈등사례를 개발사업 종류, 갈등당사자, 갈 등 쟁점, 갈등 원인, 선거공약 여부, 소송 여부에 따라 정리한 후, 갈등 예방과 해소를 위한 법과 제 도를 고찰하였다. 그리고 선거공약 또는 개발정책 및 계획안 구상단계, 개발정책 및 개발계획 수립 단계, 개발사업 시행단계, 갈등 - 분쟁 발생단계 등으로 구분하여 갈등예방 및 해소방안을 제시하였 다. 선거공약 단계에서는 공직선거법상 선거공약서 규정에 국가재정법상 예비타당성분석을 도입하 고, 개발정책 및 개발계획 수립단계에서는 전략환경평가와 갈등영향평가의 연계, 전략환경평가과정 에 사회영향평가 및 주민참여의 강화, 환경계획과 개발계획의 연계 등을 제시하였다. 개발사업 시행 단계에서는 환경영향평가 과정에서의 주민참여를 강화하고, 개발사업 시행단계에서 갈등이 발생하 는 경우 거버넌스 구축과 환경분쟁조정법, 공공기관의 갈등예방과 해결에 관한 규정 등을 근거로 하
\end{abstract}

Corresponding Author: Lee, Jong Ho, Department of Urban Planning, Cheongju University, 298 Deaseongro, Sangdang-gu, Cheongju, Chungbuk, 360-764, Republic of Korea Tel: +82-43-229-8279 Fax: 82-43-229-8233 E-mail: jhlee1013@ cju.ac.kr

* This work was supported by the research grant of Research Institute of Industrial Sciences, Cheongju University in 2011 2012. 
는 갈등해소방안을 제시하였다.

주요어 : Conflict, Conflict Impact Assessment, SEA, EIA, SIA, Public Participation, Governance.

\section{Introduction}

Since the late $80^{\prime} \mathrm{s}$, the democratization has been expedited in Korea. The various interests of many groups which had been suppressed under the authoritarian regime have become expressed explosively. The higher becomes the level of democratization, the more and the stronger become the frequency and strength of conflicts.

The grandiose developments by government have mostly made clear the value clashes between development and environmental conservation, and brought about conflicts between public interests and public environmental right, and the discordance between public interests and private property rights.

Even though the government emphasizes the benefit of development, it made decision without sufficient analysis on economic feasibility and environmental impact of development. Enormous social cost is mostly required for resolution of the conflicts resulting from development. Especially the national development projects suggested during the preceding presidential elections have resulted in socioeconomic cost unexpected. Though various institutions and legal systems have been developed and many researches on conflicts have been performed, but serious conflicts have been still brought about as before.

The previous researches have analyzed the causes of conflicts in the perspectives of interests, value differences, facts and institutional imperfection, and then have suggested public participation in the SEA and EIA process or governance as measures for conflict resolution.

To differentiate from previous studies, this study tries to suggest the solutions for prevention and resolution of conflicts stage by stage: in the designing phase, in the establishing phase, and in the implementing phase of development policy, plan and project, and in the phase of conflict occurrence.

The causes and issues of conflict will be summarized based on previous researches. The types of development plan and project and the types of parties concerned with conflict will be inquired. This study also searches the institution and legislation on conflict: election manifesto, Conflict Impact Assessment, SEA, EIA, preliminary feasibility analysis on large scale development, public participation and governance. The conflict cases in Korea will be analyzed according to the kind of conflict, the types of parties concerned with conflict, conflict issues and lawsuit. Based on the above inquiry, the possible measures for prevention and resolution of conflicts will be suggested stage by stage.

\section{Causes and Issues of Conflict}

\section{Causes of Conflict}

The causes of conflict are generally classified as interests, view of value, fact relevance, and legal regulation system. In addition, trust could be included in them.

There are many types of interests such as economic interest, environmental risk, beneficiaries (from the point of income, region, group, age, 
sex, ethnic etc.) and public or private interests. There could be also other kind of interests, which formed strongly after the suggestion of election campaign pledges.

The view of value or the point of view could include the differences of paradigm difference (development versus environmental conservation) or political stance. The fact relevance means simple misunderstanding due to communication gap, perception mistake due to distrust, and lack of confidence and rationality(scientific capacity or ability of comprehensive judgments). If the opinion of local resident would be institutionally reflected in the beginning of planning process, most conflicts could be prevented. The lack or shortage of relevant legal regulations, system or procedure is important causes of conflict(Kim, Jong Ho; Lee, Chang Hoon and Shin, Chang Hyun; Park, Jae Geun, 2004, 6-7; Jeong, Hoi Seong and Lee, Chang Hoon, 2005).

\section{Issues of Conflict}

The causes of conflict from grandiose development including the national development from presidential campaign pledge, could be categorized as environment, economic cost, social problem, cultural aspect, religion and values(Table 1). For example, the Saemangeum Reclamation Project has raised three main issues: economic aspects, water quality and water resource. In the case of the Multifunctional Administrative City, the key issues were legal aspects based on the Korean Constitution, the location issues on capital relocation after reunification of Korean Peninsula, national security and national balanced development. The disputes about the PanKorea Grand Waterway were mainly focused on the items of socioeconomic impact assessment such as the $\mathrm{B} / \mathrm{C}$ ratio, cost, employment, transport ceiling, transport time including ecosystem, water quality and water resource(Lee, Jong Ho, 2010, 200-201).

\section{Types of Stakeholder and Development Plan and Project}

\section{Types of Stakeholder and Main Participants}

\section{(1) Types of Stakeholder}

Conflicts could be classified as two types. The one is intergovernmental conflict, the other is the conflict between government and residents or NGO(Table 2). The intergovernmental conflict could be categorized as vertical and horizontal one. The vertical conflicts contain those of central government vs. large unit local self-government, central government vs. elementary local self-government, and large unit local self-government vs.

Table 1. Conflict Issues

\begin{tabular}{c|l}
\hline \hline Category & \multicolumn{1}{c}{ Conflict Issues } \\
\hline Environment & $\begin{array}{l}\text { - ecosystem } \\
\text { - environmental quality(water pollution, air pollution, solid wastes, noise etc.) } \\
\text { - water resources, flooding and drought }\end{array}$ \\
\hline Economic Aspect & - B/C ratio(economic feasibility) \\
\hline Social Problem & $\begin{array}{l}\text { - location: NIMBY(Not in my backyard), PIMFY(Please in my front yard) } \\
\text { - balanced development } \\
\text { - social consensus }\end{array}$ \\
\hline Cultural Aspect & - cultural assets \\
\hline Religion, Values & - priority preference between development and environmental conservation \\
\hline \hline
\end{tabular}


Table 2. Stakeholder concerned with Conflict

\begin{tabular}{c|c|c|c}
\hline \hline \multicolumn{2}{c|}{ Intergovernmental Conflict } & \multicolumn{2}{c}{ Government vs. Resident or NGO } \\
\hline Vertical Conflict & Horizontal Conflict & Government vs. Resident & Government vs. NGO \\
\hline $\begin{array}{c}\text { Central Government vs. Large } \\
\text { Unit Local Self-government }\end{array}$ & $\begin{array}{c}\text { Conflict between } \\
\text { Governmental Departments }\end{array}$ & $\begin{array}{c}\text { Central Government } \\
\text { vs. Resident }\end{array}$ & $\begin{array}{c}\text { Central Government } \\
\text { vs. NGO }\end{array}$ \\
\hline $\begin{array}{c}\text { Central Government vs. Elementary } \\
\text { Local Self-government }\end{array}$ & $\begin{array}{c}\text { Conflict between Large } \\
\text { Unit Local Self-governments }\end{array}$ & $\begin{array}{c}\text { Large Unit Local } \\
\text { Self-government vs. Residen }\end{array}$ & $\begin{array}{c}\text { Large Unit Local } \\
\text { Self-government vs. NGO }\end{array}$ \\
\hline $\begin{array}{c}\text { Large Unit Local Self-government vs. } \\
\text { Elementary Local Self-government }\end{array}$ & $\begin{array}{c}\text { Conflict between Elementary } \\
\text { Local Self-governments }\end{array}$ & $\begin{array}{c}\text { Elementary Local } \\
\text { Self-government vs. Resident }\end{array}$ & $\begin{array}{c}\text { Elementary Local } \\
\text { Self-government vs. NGO }\end{array}$ \\
\hline \hline
\end{tabular}

NGO(non-governmental organization): environmental organization, community organization

Source: Ministry of Government, 1999, Conflict Cases in the Local Autonomy Era, 16.

elementary local self-government. The horizontal conflicts contain the conflicts between governmental departments, between large unit local selfgovernments, and between elementary local selfgovernments.

The conflict of government vs. resident or NGO can be categorized as that of government vs. resident and that of government vs. NGO. The conflicts of government vs. resident contain those of central government vs. resident, large unit local self-governments vs. resident, and elementary local self-government vs. resident. The conflicts of government vs. NGO contain those of central government vs. NGO, large unit local selfgovernment vs. NGO, and elementary local selfgovernment vs. NGO.

In addition to above classification, there could be other conflicts: those of ruling party vs. opposition party, pro-government specialist vs. antigovernment specialist, developer vs. environmental NGO, and foreign investment enterprise vs. government, resident and environmental NGO.

\section{(2) Proposer and Implementer of Development Plan and Project}

The government or enterprise proposes and implements development project. The development implemented by government also could be classified as two: one from problem identification and the other from presidential campaign pledges. The latter is at some case suggested without sufficient study on economic feasibility, environmental conservation, social problem, and cultural asset etc. The development implemented by government could make impact locally or on a national scale; in the short-term, mid-term and long-term.

The development project could be implemented by domestic company or by foreign company. Serious conflict could be brought about by foreign company. In case that some foreign company invests in Korea, there could be the possibility of conflict due to Investor-State Dispute under FTA(Free Trade Association) concluded with the company's homeland. For example, Billcon has brought suit against Canadian government with violations of NAFTA 1102, 1103 and 1105, insisting that Canada discriminated against Billcon intentionally(Lee, Taewha, 2012, 529-534).

\section{Types of Development Plan and Project}

According to Environmental Impact Assessment (EIA) Act, there are 17 development plans which are the target of Strategic Environmental Assessment(SEA) and 17 development projects which are the target of project-EIA: urban development, industrial location - industrial complex, energy development, harbour construction, road 
construction, water resource development and so opment projects which are the target of small forth. And there are development areas or develscale EIA(Table 3).

Table 3. Development Plan and Development Project as Target of SEA and EIA

\begin{tabular}{|c|c|c|c|}
\hline \multicolumn{2}{|c|}{ Target of SEA } & \multirow{2}{*}{ Target of EIA } & \multirow{2}{*}{ Target of small scale EIA } \\
\hline Policy Plan & Development Basic Plan & & \\
\hline urban development & urban development & urban development project & \multirow{17}{*}{$\begin{array}{l}\text { - area where Act on Planning } \\
\text { and Utilization of the National } \\
\text { Territory is applied } \\
\text { - area where Special Act on } \\
\text { Designation and Management } \\
\text { of Green Belt is applied } \\
\text { - area where Natural Environment } \\
\text { Conservation Act and Act on } \\
\text { Preservation and Management } \\
\text { of Wild Animal are applied } \\
\text { - area where Forest Management } \\
\text { Act is applied } \\
\text { - area where Natural Parks Act } \\
\text { is applied } \\
\text { - area where Wetlands } \\
\text { Conservation Act is applied } \\
\text { - area where Water Supply } \\
\text { and Waterworks Installation } \\
\text { Act, River Act, Small River } \\
\text { Maintenance Act and } \\
\text { Groundwater Act are } \\
\text { applied } \\
\text { - area where Grassland Act is } \\
\text { applied } \\
\text { - the other development } \\
\text { projects }\end{array}$} \\
\hline- & $\begin{array}{l}\text { industrial location and } \\
\text { industrial complex }\end{array}$ & $\begin{array}{c}\text { industrial location and industrial } \\
\text { complex development project }\end{array}$ & \\
\hline- & energy development & energy development project & \\
\hline- & harbour construction & harbour construction project & \\
\hline road construction & road construction & road construction project & \\
\hline water resource development & water resource development & water resource development project & \\
\hline railroad construction & railroad construction & $\begin{array}{l}\text { railroad construction project } \\
\text { (including urban railroad) }\end{array}$ & \\
\hline- & airport construction & airport construction project & \\
\hline- & river use and development & river use and development project & \\
\hline- & $\begin{array}{c}\text { reclamation and public } \\
\text { waters landfill }\end{array}$ & $\begin{array}{c}\begin{array}{c}\text { reclamation and public waters } \\
\text { landfill project }\end{array} \\
\end{array}$ & \\
\hline tourism complex development & $\begin{array}{c}\text { tourism complex } \\
\text { development }\end{array}$ & $\begin{array}{l}\text { tourism complex development } \\
\text { project }\end{array}$ & \\
\hline forest development & forest development & forest development project & \\
\hline special region development & special region development & special region development project & \\
\hline- & physical plant installation & physical plant installation project & \\
\hline $\begin{array}{c}\text { treatment facilities installation } \\
\text { of wastes, night soil, and } \\
\text { livestock excretions }\end{array}$ & $\begin{array}{c}\text { treatment facilities installation } \\
\text { of wastes, night soil, } \\
\text { and livestock excretions }\end{array}$ & $\begin{array}{l}\text { treatment facilities installation } \\
\text { of wastes, night soil and } \\
\text { livestock excretions }\end{array}$ & \\
\hline 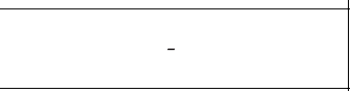 & $\begin{array}{l}\text { national defense and military } \\
\text { facilities installation }\end{array}$ & $\begin{array}{l}\text { national defense and military } \\
\text { facilities installation project }\end{array}$ & \\
\hline- & $\begin{array}{l}\text { collection of avalanches, } \\
\text { sand, gravel and mineral }\end{array}$ & $\begin{array}{c}\text { collection project of avalanches, } \\
\text { sand, gravel and mineral }\end{array}$ & \\
\hline
\end{tabular}

SEA: Strategic Environmental Assessment

EIA: Environmental Impact Assessment

Table 4. Institution and Legislation on Conflict in Korea

\begin{tabular}{|c|c|c|}
\hline Planning Process & Institution & Legislation \\
\hline Election Pledge & Election Manifesto & Public Official Election Act \\
\hline Policy & Conflict Impact Assessment & $\begin{array}{l}\text { Enactment on Conflict Prevention and } \\
\text { Resolution of Public Institution }\end{array}$ \\
\hline \multirow{3}{*}{ Development Plan } & $\begin{array}{l}\text { SEA (Ministry of Land, Transport } \\
\text { and Maritime Affairs) }\end{array}$ & Enactment on Strategic Environmental Assessment \\
\hline & $\begin{array}{l}\text { National Planning Assessment(Ministry of } \\
\text { Land, Transport and Maritime Affairs) }\end{array}$ & $\begin{array}{l}\text { Framework Act on the National Land } \\
\text { Guideline for National Planning Assessment }\end{array}$ \\
\hline & SEA (Ministry of Environment) & Environmental Impact Assessment Act \\
\hline \multirow{3}{*}{ Development Project } & $\begin{array}{c}\text { Preliminary Feasibility Analysis: } \\
\text { Economic Feasibility, Policy Analysis }\end{array}$ & National Finance Act \\
\hline & EIA: Public Participation & Environmental Impact Assessment Act \\
\hline & Small Scale Project-EIA & Environmental Impact Assessment Act \\
\hline Project Implementation & & Environmental Dispute Adjustment Act \\
\hline
\end{tabular}




\section{Institution and Legislation on Conflict in Korea}

In Korea, there are various institutions and legislations for prevention and resolution of conflicts(Table 4). These will be explained in the order of phase.

\section{Election Manifesto}

Public Official Election Act is applied to the election of president, members of the National Assembly, local councilor and head of local government agency. According to the Article 66 of the act, the objectives, order of priority, implementation procedure, implementation period, and funding measures of development projects should be specified as implementation plan in the election manifesto.

\section{Conflict Impact Assessment}

In the Article 10 of Enactment on Conflict
Prevention and Resolution of Public Institution, conflict impact assessment can be implemented before decision making of public policy, when it is judged that the public policy would bring about significant and widespread impact on people or enormous social cost would happen due to conflicting interests.

The conflict impact analysis statement includes summary and expected effects of public policy, identification of stakeholder and soundings, opinion of related groups and experts, cause of conflict and main controversial issues expected, social impact of conflict, and concrete plan for prevention and resolution of conflicts etc.

\section{SEA and EIA}

In Korea, there are two kinds of SEA: SEA on the long-term basic plans by Ministry of Land, Transport, and Maritime Affairs, and SEA on the administrative plans by Ministry of Environment. The long-term basic plan is above the administra-

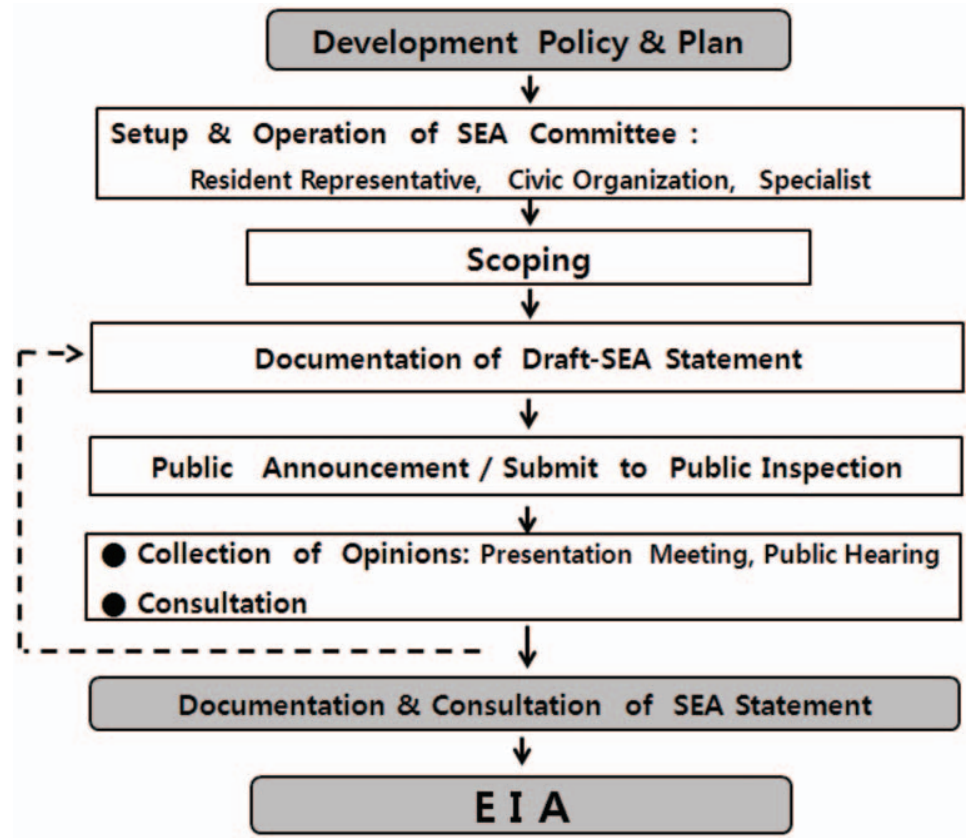

Figure 1. SEA Procedure in Korea 


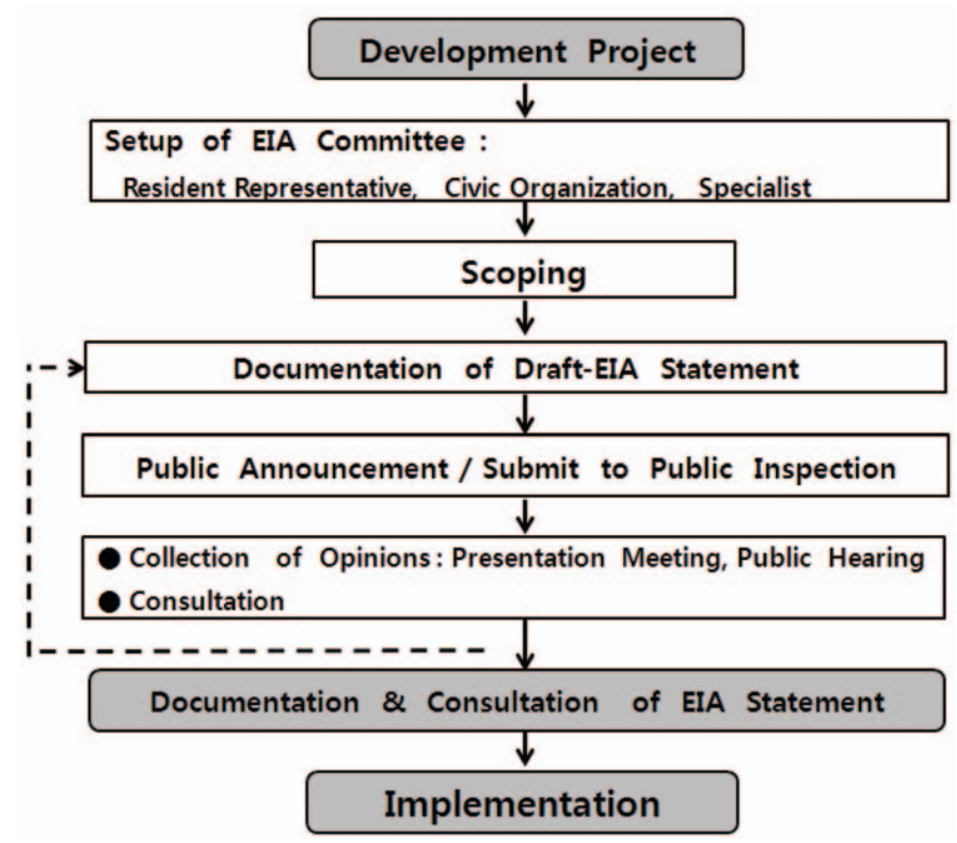

Figure 2. EIA Procedure in Korea

tive plans in order of rank. The procedure of SEA and EIA includes public participation such as presentation meeting and public hearing for collection of opinion in order to prevent conflicts from development plan and development project according to the Article 13 and the Article 25 of EIA Act(Figure 1, Figure 2).

In addition to explicit SEA as seen above, there is a quasi-SEA called as "National Planning Assessment" based on Framework Act on the National Land. According to the "Guideline for National Planning Assessment," National Planning Assessment is defined as assessing planning related with national land planning in the perspectives of national balancing development, buildup of competitive national land and environmentally friendly national land management,

\section{Preliminary Feasibility Analysis}

National Finance Act has the purpose to oper- ate finances which are efficient, result-oriented and transparent, and to establish the foundation of sound finance by defining finance related matters such as national budget, fund, balancing account, performance management and government debt.

According to the act, the Minister of Strategy and Finance should carry out the preliminary feasibility analysis in order to compile the budget for large scale development project, of which the total expenditure is more than 50 billion Korean Won and of which the amount supported by central government is more than 30 billion Korean Won.

\section{Environmental Dispute Adjustment Act}

The purposes of this act are environmental conservation and remedying damage of health and property by defining the procedure of environmental dispute adjustment and by resolving environmental dispute rapidly, fairly and effec- 
tively.

There have been established the Central Commission on Environmental Dispute Adjustment in the Ministry of Environment; and the Local Commission on Environmental Dispute Adjustment in Seoul Metropolitan City, metropolitan cities, provinces, and Special Self-Governing Province (Jeju). The jurisdiction of the Commission on Environmental Dispute Adjustment are adjustment of environmental dispute; survey, analysis and consulting of civil complains concerning environmental damage; research and suggestion of institutions and policy for prevention and resolution of dispute; and education and public relations related with prevention and remedy of environmental damage.

\section{Conflict Cases in Korea}

\section{Presidential Campaign Pledges}

Where do the national development projects come from? The three grandiose national development projects: Saemangeum Reclamation Project, the New Capital City, and the Four Major Rivers Restoration Project have been originated from the presidential campaign pledges. It has been insisted that the presidential campaign pledges come from vote-gathering by use of regional difference or regional characteristics(Lee, Jong Ho, 2004).

Saemangeum Reclamation Project was suggested as the presidential campaign pledge(Dec. 1987), and gathered many supporting votes from the residents in Chonbuk region where the project would be implemented, and the president candidate was elected as president(Hong, Wkhee, 2004). After 15 years later, another president candidate suggested the New Capital City(Multifunctional Administrative City) to get support from Chungcheong region in Dec. 2002. The PanKorea Grand Waterway was suggested in Dec. 2007, targeting votes of the whole nation. The waterway project was different from the previous presidential campaign pledges which could confer benefits on only one local province or special region. The president candidate could succeed in the presidential election, but the Pan-Korea Grand Waterway has been changed to the Four Major Rivers Restoration Project due to strong opposition and resistance.

The grandiose national developments were promised without sufficient preliminary socioeco-

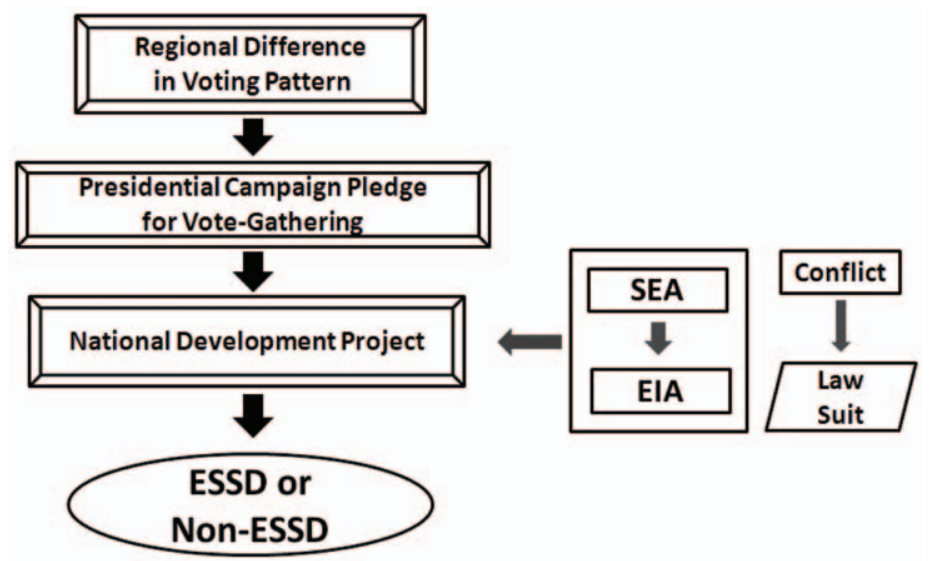

Figure 3. Presidential Campaign Pledge and Conflict 


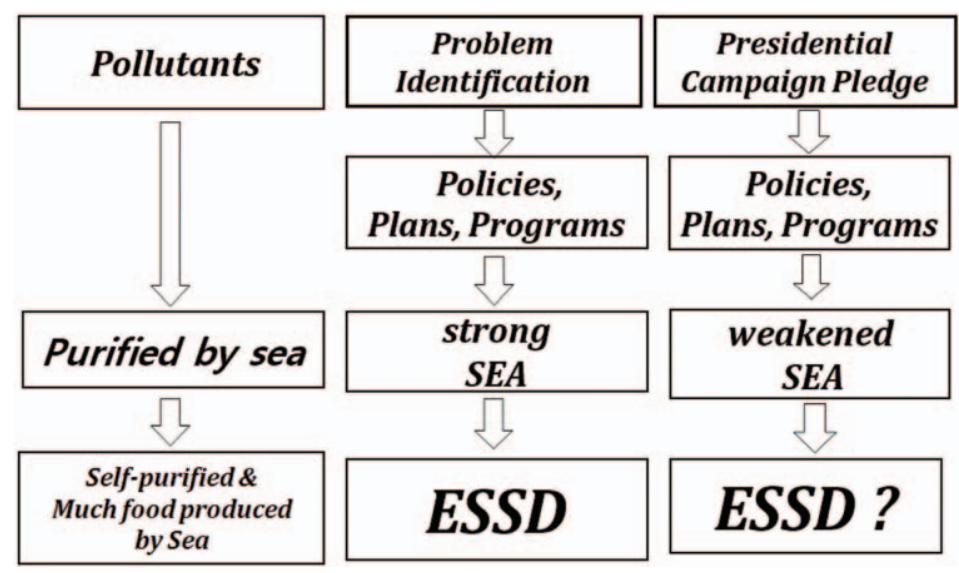

Figure 4. SEA on Development Plan

nomic feasibility analysis. Though SEA has been done, the implementation of the presidential campaign pledges resulted in strong resistance and serious conflicts. The resident, NGO and some specialists requested the more detailed environmental survey and finally sued without few exceptions. The supreme court sentenced to recommencing the national development project temporarily stopped, emphasizing continuity of national policy. The result entailed enormous delaying cost and environmental cost. Consequently all people should pay much more tax than ever before(Lee, Jong Ho, 2010, 199 201, Figure 3).

SEA and EIA, which were weakened by the reason of presidential campaign pledges, cannot help doing only the role of passage rite to justify the development, while sea purifies most pollutants to protect the ecosystem(Figure 4).

\section{Large scale Development Project}

Various large scale development projects have been undertaken during the last 25 years(Table 5). They could be categorized as urban development, industrial complex, water resources development such as dam and canal, and tunnel construction etc.
In the cases of Onsan Industrial Complex and Yeosu Industrial Complex constructed in 1980's, there was no lawsuit during the period of construction and operation, even though the air pollution was very heavy. In the long run, the resident had no choice but to move to other places under the support of government.

The development projects such as Anmyeondo nuclear waste storage site and Buan(Weedo) nuclear waste storage site were cancelled before lawsuit due to very strong opposition by the resident. In case of dam development projects such as Youngweol(Dong River) Dam and Hantan River Dam, the governance system: expert review panel and Presidential Commission on Sustainable Development had done very important role in resolving the conflicts.

\section{Prevention and Resolution of Conflict}

Connecting the institutions and legislations on conflict with conflict cases, the measures for prevention and resolution of conflict are drawn as Table 6. 
Table 5. Issues, Causes, Parties and Lawsuit of Conflicts in Korea

\begin{tabular}{|c|c|c|c|c|c|c|c|c|}
\hline $\begin{array}{l}\text { Name of } \\
\text { Development } \\
\text { Project }\end{array}$ & $\begin{array}{c}\text { Category of } \\
\text { Development } \\
\text { Project }\end{array}$ & $\begin{array}{l}\text { Beginning } \\
\text { Period }\end{array}$ & $\begin{array}{l}\text { Presidential } \\
\text { Campaign } \\
\text { Pledges }\end{array}$ & Stakeholder & $\begin{array}{l}\text { Conflict } \\
\text { Issues }\end{array}$ & $\begin{array}{c}\text { Causes of } \\
\text { Conflict }\end{array}$ & Governance & Lawsuit \\
\hline & & & & & $\begin{array}{l}\text { (1) economy } \\
\text { (2) environment } \\
\text { (3) ecosystem } \\
\text { (4) social aspect } \\
\text { (1ocation, } \\
\text { unification) }\end{array}$ & $\begin{array}{l}\text { (1) interests } \\
\text { (2) values } \\
\text { (3) fact: } \\
\text { acknowledge } \\
\text { ment, scientific } \\
\text { ability } \\
\text { (4) institution }\end{array}$ & & $\begin{array}{l}\text { (1) implementation without } \\
\text { lawsuit } \\
\text { (2) cancel without lawsuit } \\
\text { (3) implementation after } \\
\text { lawsuit } \\
\text { (4) cancel after hawsult }\end{array}$ \\
\hline $\begin{array}{c}\text { Saemangeum } \\
\text { Reclamation Project }\end{array}$ & reclamation & 1987 & Y & $\begin{array}{l}\text { central government, local } \\
\text { self-government (Chonbuk) } \leftrightarrow \\
\text { environmental NGO }\end{array}$ & (1), (2), (3) & (1), (2), (3), (4) & & (3) \\
\hline New Capital City & new town & 2002 & Y & $\begin{array}{c}\text { central government } \leftrightarrow \\
\text { opposition party }\end{array}$ & (4) & (1), (2) & & (3) \\
\hline $\begin{array}{c}\text { Pan-Korea } \\
\text { Grand Waterway }\end{array}$ & water resources & $2007-2008$ & Y & $\begin{array}{c}\text { central government } \leftrightarrow \text { opposition } \\
\text { party, environmental NGO }\end{array}$ & (1), (2), (3) & & & (2) \\
\hline $\begin{array}{l}\text { Four Major Rivers } \\
\text { Restoration Project }\end{array}$ & water resources & 2009 & Y & $\begin{array}{c}\text { central government } \\
\text { opposition party, environmental NGO }\end{array}$ & (1), (2), (3) & (1), (2, (3) & & (3) \\
\hline Onsan Industrial Complex & industrial complex & 1983 & & central government resident & (2), (3) & (1), (3), (4) & & (1)(resident moving) \\
\hline $\begin{array}{l}\text { Siwha } \cdot \text { Banweol } \\
\text { Industrial Complex }\end{array}$ & industrial complex & 1987 & & $\begin{array}{l}\text { central government } \\
\leftrightarrow \text { environmental NGO }\end{array}$ & (2), (3) & (1), (3), (4) & $\begin{array}{l}\text { Siwha Commission } \\
\text { on Sustainable } \\
\text { Development, } 2003\end{array}$ & (1) \\
\hline Yeosu Industrial Complex & industrial complex & late 1980's & & central government↔resident & (2), (3) & (1) & & (1) (resident moving) \\
\hline $\begin{array}{l}\text { Weecheon Industrial } \\
\text { Complex }\end{array}$ & industrial complex & 1990 's & & $\begin{array}{c}\text { local self-government(Daegu) } \leftrightarrow \\
\text { local self-government(Busan) }\end{array}$ & (2) & (1) & & (1) \\
\hline $\begin{array}{c}\text { Youngweol } \\
\text { (Dong River)Dam }\end{array}$ & dam & 1997 & & $\begin{array}{c}\text { central government } \leftrightarrow \text { local } \\
\text { self-government(Jeongseon Gun), } \\
\text { resident, environmental NGO }\end{array}$ & (2), (3) & (1), (2), (3) & Expert Review Panel & (2) \\
\hline Hantan River Dam & dam & 2000 & & $\begin{array}{c}\text { central government, K-Water } \\
\text { resident, environmental NGO }\end{array}$ & (2), (3), (4) & (1), (2), (3), (4) & \begin{tabular}{|c|} 
Presidential Commission \\
on Sustainable \\
Development
\end{tabular} & (3) \\
\hline Gyeongin Canal & canal & 2003 & Y & $\begin{array}{l}\text { central government } \\
\leftrightarrow \text { environmental NGO }\end{array}$ & (1), (2), (3) & (1), (2), (3), (4) & & (1) \\
\hline Sapaesan Tunnel & tunnel & 1987 & Y & $\begin{array}{l}\text { central government } \leftrightarrow(\text { central } \\
\text { government), Buddhism circle, } \\
\text { resident, environmental NGO }\end{array}$ & (1), (2), (3), (4) & (1), (2) & & (3) \\
\hline $\begin{array}{c}\text { Gyongbu High Speed } \\
\text { Railroad Cheonseongsan } \\
\text { Tunnel }\end{array}$ & tunnel & 2002 & & $\begin{array}{l}\text { central government } \leftrightarrow \text { Buddhism } \\
\text { circle, environmental NGO }\end{array}$ & (2, (3) & (1), (2), (3) & & (3) \\
\hline $\begin{array}{l}\text { Anmyeondo nuclear } \\
\text { waste storage site }\end{array}$ & $\begin{array}{l}\text { nuclear waste } \\
\text { storage site }\end{array}$ & 1990 & & central government↔resident & (2), (3) & (1), (2), (4) & & (2) \\
\hline $\begin{array}{l}\text { Buan(Weedo) nuclear } \\
\text { waste storage site }\end{array}$ & $\begin{array}{l}\text { nuclear waste } \\
\text { storage site }\end{array}$ & 2003 & & $\begin{array}{l}\text { local self-government. central } \\
\text { government } \leftrightarrow \text { resident, } \\
\text { environmental NGO }\end{array}$ & (2, (3) & (1), (3), (4) & & (2) \\
\hline
\end{tabular}

Sources: Jeong, Hoi Seong and Lee, Chang Hoon, 2005, Current State of Environmental Conflict and Policy Tasks, Economic, Cultural and Social Research Committee, 8, 342. Jeong, Hoi Seong; Jo, Gong Jang; Lee, Chang Hoon and Park, Hee Oong, 2006, Governance and Environmental Conflict Management related with Water Resource Planning, Korea Environment Institute, 11.

Kim, Jong Ho; Lee, Chang Hoon; Shin, Chang Hyun, and Park, Jae Geun, 2004, Environmental Conflict Category and Measures for Resolution, Korea Environment Institute, 9. Kim, Sun-Hee, Jo, Jin-Chu, Park, Hyung-Seo, 2005, Establishment of Consensus Building System for the Efficient Implementation of National Development Project, Korea Research Institute of Human Settlement, 39-113.

Park, Hyung Seo et al., 2005, Fundamental Study on Public Conflict Prevention and Management System Establishment, Ministry of Construction and Transportation, 37-42. 
Table 6. Measures for Prevention and Resolution of Conflict

\begin{tabular}{|c|c|c|c|}
\hline From Policy to Conflict & $\begin{array}{l}\text { Measures for Prevention } \\
\text { and Resolution of Conflict }\end{array}$ & Role of Measure & Applicable Target \\
\hline \multirow{2}{*}{$\begin{array}{c}\text { Designing Phase of } \\
\text { Development } \\
\text { Policy and Plan }\end{array}$} & Election manifesto & prevention & $\begin{array}{l}\text { project from presidential } \\
\text { campaign pledges }\end{array}$ \\
\hline & Preliminary Feasibility Analysis & prevention & $\begin{array}{c}\text { project from presidential campaign } \\
\text { pledges }\end{array}$ \\
\hline \multirow{4}{*}{$\begin{array}{c}\text { Establishing Phase of } \\
\text { Development Policy, } \\
\text { Plan and Project }\end{array}$} & $\begin{array}{c}\text { Linking Conflict Impact } \\
\text { Assessment and SEA \& EIA }\end{array}$ & prevention & policy, plan and project \\
\hline & $\begin{array}{l}\text { Strengthening of SIA in the } \\
\text { process of SEA and EIA }\end{array}$ & $\begin{array}{l}\text { prevention and } \\
\text { mitigation }\end{array}$ & plan and project \\
\hline & $\begin{array}{l}\text { Public Participation in } \\
\text { SEA and EIA }\end{array}$ & $\begin{array}{l}\text { prevention and } \\
\text { mitigation }\end{array}$ & plan and project \\
\hline & $\begin{array}{l}\text { Linking Development Plan and } \\
\text { Environmental Plan }\end{array}$ & prevention & plan \\
\hline \multirow{2}{*}{$\begin{array}{c}\text { Implementing Phase of } \\
\text { Development } \\
\text { Project and Conflict } \\
\text { Occurrence }\end{array}$} & Governance & conflict resolution & $\begin{array}{l}\text { - industrial complex, dam, canal } \\
\text { - development project implemented } \\
\text { without lawsuit }\end{array}$ \\
\hline & $\begin{array}{c}\text { Commission on Environmental } \\
\text { Dispute Adjustment }\end{array}$ & $\begin{array}{c}\text { conflict adjustment } \\
\text { and resolution }\end{array}$ & $\begin{array}{l}\text { project with which } \\
\text { government is not concerned }\end{array}$ \\
\hline \multirow[t]{2}{*}{ Future Task } & $\begin{array}{l}\text { Integration of SEA(by Ministry of } \\
\text { Land, Transport and Maritime Affairs) } \\
\text { and SEA(by Ministry of Environment) }\end{array}$ & prevention & policy and plan \\
\hline & $\begin{array}{c}\text { Real-name System on } \\
\text { Plan and Project }\end{array}$ & prevention & $\begin{array}{c}\text { project from presidential campaign } \\
\text { pledges }\end{array}$ \\
\hline
\end{tabular}

\section{Designing Phase of Development Policy and Plan: Presidential Campaign Pledges}

In order to prevent conflicts from the presidential campaign pledges, the strict regulation on election manifesto should be carried out. So it could be argued that the election manifesto should include the preliminary feasibility analysis on large scale development projects based on National Finance Act.

\section{Establishing Phase of Development Policy and Plan}

\section{(1) Linking and Integration of Conflict Impact Assessment and SEA}

In case that SEA and EIA are implemented based on the Article 9 and the Article 27 of EIA Act, and traffic impact analysis and improvement are implemented based on Urban Traffic
Improvement Promotion Act and the techniques on conflict impact analysis are applied according to the Article 10 of Enactment on Conflict Prevention and Resolution of Public Institution; then the conflict impact analysis is regarded as to be done.

Therefore conflict impact assessment had better be done before or during the SEA process and EIA process. Judging from the development projects cancelled due to conflict in its beginning period before lawsuit, it could be argued that the conflict impact assessment before the process of SEA and EIA can prevent the conflict.

\section{(2) Strengthening Social Impact Assessment (SIA) in the Process of SEA}

SIA is known to focus on the predictions about social change, or to focus on the facilitation of public participation in decision-making 
through systematic identification of affected parties, documentation of community viewpoints, and convening of forums to share and to debate these data(Lockie, et al., 2008).

The socioeconomic impacts by the national development projects should be discussed open to the public, and SEA reflecting SIA should be implemented.

Therefore in the SEA process, should be reflected the socioeconomic assessment items such as the social consensus among related regions, interested political parties or groups and various income groups; economic aspects (B/C ratio, cost, employment etc.), legal aspects, and political aspects such as the possibility of Korean Peninsula reunification, regional disparity, and national balanced development(Lee, Jong Ho, 2010, 202).

At present EIA, the items included in the socioeconomic environment are population, housing and industry. For successful SIA, the scope of socioeconomic environment should be expanded to public facilities, education, transportation, cultural assets, economic feasibility, employment and other economic items(Lee, Jong Ho, 2010, 202).

\section{(3) Public Participation in the Process of SEA}

If the public participation would be institutionally included in the beginning of planning process and SEA procedure, most conflict could be prevented.

Of course, the public participation system is reflected in EIA Act lately drastically revised. The relevant resident participation system such as presentation meeting and public hearing for collection of opinion for preventing conflicts has become included in the EIA Act.

\section{(4) Linking Development Plan and Environmental Plan}

There are many development plans and environmental plans at various levels such as nation level, province or metropolitan level, city or county level and district level. In case development plan and environmental plan are interlinked well, the possibility of conflict would remarkably decrease, which could be interpreted as "implicit" SEA(Lee, Jong Ho, 2007, 443).

\section{Implementing Phase of Development Project and Conflict Occurrence}

The Environmental Dispute Resolution Commission based on the Environmental Dispute Adjustment Act, cannot carry out the role of adjustment for the national development with which government is concerned.

Therefore the governance is necessary for the resolution of conflicts with which government is concerned(Figure. 5). In case of Siwha - Banweol Industrial Complex, Youngweol(Dong River) Dam, and Hantan River Dam, the governance systems such as Siwha Commission on Sustainable Development (2003), Expert Review Panel, and PCSD (Presidential Commission on Sustainable Development) have done very important role in the governance system(Kim, Jong Ho; Lee, Chang

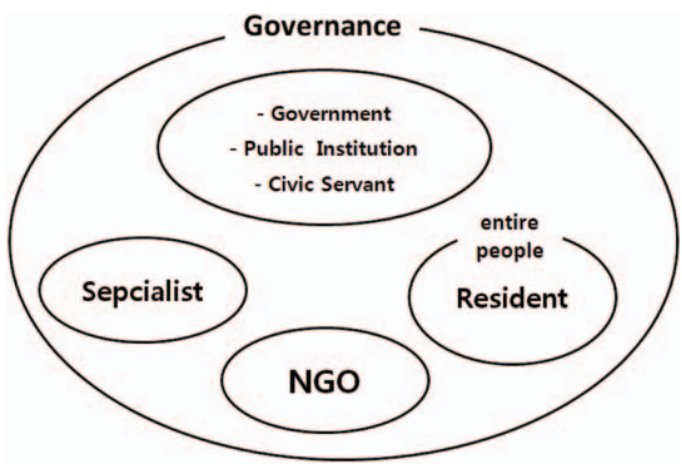

Figure 5. Governance 
Hoon; Shin, Chang Hyun, and Park, Jae Geun, 2004; Jeong, Hoi Seong and Lee, Chang Hoon, 2005, 347-349).

\section{Future Task}

\section{(1) Integration of SEA's by two Ministries}

In order to prevent conflicts, it is desirable that the Enactment on SEA of Ministry of Land, Transport and Maritime Affairs should be integrated with SEA included in the EIA Act for completely integrated environmental assessment system.

\section{(2) Real-name System on Plan and Project}

There has been no responsibility for the asserter who brings about the failure of plan or project, but the irresponsibility for plan and project could result in the tax bomb to the whole people. Therefore Real-name Plan and Project System are indispensable in order to prevent conflicts and their socioeconomic cost.

\section{Concluding Remarks}

In the past, the policy and plan was decided by government and specialist, but the resident affected by the policy and plan could not participate in the decision making process of policy and plan. The plan and policy had been decided behind closed doors for fear of side effect, and the ex post facto persuasion and compensation were the only alternatives for resolving conflicts aroused. Nowadays it has become impossible to implement the plan and project without related resident participation.

This study suggests the measures for prevention and resolution of conflicts, dividing all the procedure into the designing phase, the establish- ing phase and the implementing phase of development policy, plan and project and conflict occurrence.

The preliminary feasibility analysis based on National Finance Act should be included in the election manifesto of presidential campaign pledges. In the establishing phase of development policy and plan, linking and integration of Conflict Impact Assessment and SEA, strengthening SIA and public participation in the process of SEA and linking development plan and environmental plan should be realized. When conflict occurs in the implementing phase of development project, the governance composed of public servant, specialist and related resident should be organized.

In the long term, the integration of SEA of Ministry of Land, Transport and Maritime Affairs and that of Ministry of Environment should be considered and come to the realization.

And there should be the real-name system on policy and plan documenting the person who devised or suggested election campaign pledges, and planned and implemented the development projects. The system could prevent conflicts by emphasizing and recording the persons in charge.

\section{References}

Hong, Wk-hee, 2004, Environmental Dispute on the Saemangeum Reclamation Project, Jiseongsa.

Jeong, Hoi Seong and Lee, Chang Hoon, 2005, Current State of Environmental Conflict and Policy Tasks, Economic, Cultural and Social Research Committee, 8, 342, 347-349. Jeong, Hoi Seong; Jo, Gong Jang; Lee, Chang 
Hoon and Park, Hee Oong, 2006, Environmental Governance and Conflict Management for Water Resource Development Policy and Projects, Korea Environment Institute, 11.

Kim, Jong Ho; Lee, Chang Hoon; Shin, Chang Hyun and Park, Jae Geun, 2004, Environmental Conflict Category and Measures for Resolution, Korea Environment Institute, 9.

Kim, Sun-Hee, Jo, Jin-Chu, Park, Hyung-Seo, 2005, Establishment of Consensus Building System for the Efficient Implementation of National Development Project, Korea Research Institute of Human Settlement, 39-113.

Lee, Jong Ho, 2004, New Capital City Construction and Saemangeum Reclamation Project and Presidential Election, Environment and Future, 51, Association for Environment and Pollution.

Lee, Jong Ho, 2008, "Environmental Conflicts and SIA," Journal of Korean Society Researches, 30(2), Social Sciences Institute, Cheongju University, 29-51.

Lee, Jong Ho, 2010, “Social Impact Assessment on National Development Projects in Korea," Journal of Environmental Impact Assessment, 19(2), Korean Society of Environmental Impact Assessment, 197-204.

Lee, Jong Ho and Cho, Jae Heon, 2007, "Strategic Environmental Assessment and Integration of Development and Environmental
Planning in Korea," Journal of Environmental Impact Assessment, 16(6), Korean Society of Environmental Impact Assessment, 433446.

Lee, Taehwa, 2012, The Possibility of InvestorState Dispute under Korea US FTA in relation to Korean Environmental Impact Assessment: A Lesson from Billcon vs. Canada under NAFTA, Journal of Environmental Impact Assessment, 21(4), Korean Society of Environmental Impact Assessment, 525-541.

Lockie, Stewart; Franetovich, Maree; Sharma, Sanjay; and Rolfe, John, 2008, “Democratization versus engagement? Social and economic impact assessment and community participation in the coal mining industry of the Bowen Basin, Australia," Impact Assessment and Project Appraisal, 26(3), International Association for Impact Assessment, 177-187.

Ministry of Government, 1999, Conflict Cases in the Local Autonomy Era, 16.

Park, Hyung Seo et al., 2005, Fundamental Study on Public Conflict Prevention and Management System Establishment, Ministry of Construction and Transportation, $37-42$.

최종원고채택 13. 01. 24 